\title{
8AREL
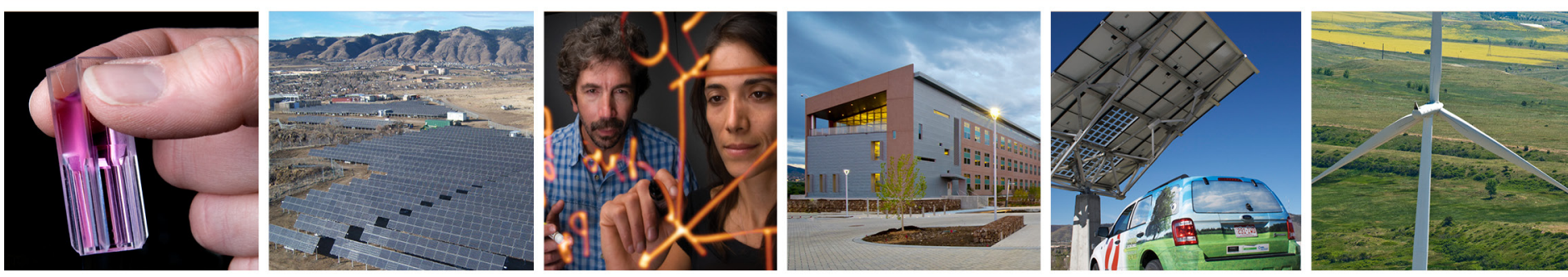

\section{A Review of Operational Water Consumption and Withdrawal Factors for Electricity Generating Technologies}

Jordan Macknick, Robin Newmark, Garvin Heath, and KC Hallett 


\section{A Review of Operational Water Consumption and Withdrawal Factors for Electricity Generating Technologies}

Jordan Macknick, Robin Newmark, Garvin Heath, and KC Hallett

Prepared under Task No. DOCC.1005 


\section{NOTICE}

This report was prepared as an account of work sponsored by an agency of the United States government. Neither the United States government nor any agency thereof, nor any of their employees, makes any warranty, express or implied, or assumes any legal liability or responsibility for the accuracy, completeness, or usefulness of any information, apparatus, product, or process disclosed, or represents that its use would not infringe privately owned rights. Reference herein to any specific commercial product, process, or service by trade name, trademark, manufacturer, or otherwise does not necessarily constitute or imply its endorsement, recommendation, or favoring by the United States government or any agency thereof. The views and opinions of authors expressed herein do not necessarily state or reflect those of the United States government or any agency thereof.

Available electronically at http://www.osti.gov/bridge

Available for a processing fee to U.S. Department of Energy and its contractors, in paper, from:

U.S. Department of Energy

Office of Scientific and Technical Information

P.O. Box 62

Oak Ridge, TN 37831-0062

phone: 865.576.8401

fax: 865.576 .5728

email: mailto:reports@adonis.osti.gov

Available for sale to the public, in paper, from:

U.S. Department of Commerce

National Technical Information Service

5285 Port Royal Road

Springfield, VA 22161

phone: 800.553 .6847

fax: 703.605.6900

email: orders@ntis.fedworld.gov

online ordering: http://www.ntis.gov/help/ordermethods.aspx

Cover Photos: (left to right) PIX 16416, PIX 17423, PIX 16560, PIX 17613, PIX 17436, PIX 17721

Printed on paper containing at least $50 \%$ wastepaper, including $10 \%$ post consumer waste. 


\section{Acknowledgments}

This work was funded by the U.S. Department of Energy's (DOE's) Office of Energy Efficiency and Renewable Energy (EERE) and Office of Policy and International Affairs (PI). The authors wish to thank Allan Hoffman and Diana Bauer for their support of this work. We are also indebted to the following individuals for their thoughtful comments, input, and review of the document in its various stages: Kristen Averyt, Western Water Assessment (WWA) and the University of Colorado; Stacy Tellinghuisen, Western Resource Advocates; Timothy Diehl, U.S. Geological Survey; and Lynn Billman, Elaine Hale, Margaret Mann, Walter Short, and Daniel Steinberg, NREL. In addition, we would like to thank the participants in the Water for Energy Workshop who provided valuable input, particularly Christina Alvord and Brad Udall, WWA and University of Colorado; Mike Hightower and Vince Tidwell, Sandia National Laboratories; Curt Brown, U.S. Bureau of Reclamation; Margot Gerritsen, Stanford University; Eric Fournier, UC Santa Barbara; Alex Schroeder, Western Governors' Association; Ashlynn Stillwell, University of Texas Austin; Steve Clemmer and John Rogers, Union of Concerned Scientists; Andrew Wolfsberg, Los Alamos National Laboratory; and Larry Flowers, NREL. We also wish to thank Mary Lukkonen of NREL for her editorial support. 


\section{Executive Summary}

This report provides estimates of operational water withdrawal and water consumption factors for electricity generating technologies in the United States. Estimates of water factors were collected from published primary literature and were not modified except for unit conversions. The presented water factors may be useful in modeling and policy analyses where reliable power plant level data are not available. Major findings of the report include:

- The power sector withdraws more water than any other sector in the United States and is heavily dependent on available water resources. Changes in water resources may impact the reliability of power generation.

- Water withdrawal and consumption factors vary greatly across and within fuel technologies. Water factors show greater agreement when organized according to cooling technologies as opposed to fuel technologies. Once-through cooling technologies withdraw 10 to 100 times more water per unit of electric generation than recirculating cooling technologies; recirculating cooling technologies consume at least twice as much water as once-through cooling technologies.

- A transition to a less carbon-intensive electricity sector could result in either an increase or decrease in water use, depending on the choice of technologies and cooling systems employed. Concentrating solar power (CSP) technologies and coal facilities with carbon capture and sequestration (CCS) capabilities have the highest water consumption values when using a recirculating cooling system. Non-thermal renewables, such as photovoltaics (PV) and wind, have the lowest water consumption factors.

- Federal datasets on water use in power plants have numerous gaps and methodological inconsistencies. Federal agencies are currently coordinating to improve these data. Water use factors discussed here are good proxies for use in modeling and policy analyses, at least until power plant level data improve.

- Impacts of the power sector on freshwater availability can be reduced by utilizing dry cooling or by using non-freshwater sources for cooling. However, these alternatives are limited by locally available resources and may have cost and performance penalties.

Improved power plant data and further studies into the water requirements of energy technologies in different climatic regions would facilitate greater resolution in analyses of water impacts of future energy and economic scenarios. This report provides the foundation for conducting water use impact assessments of the power sector while also identifying gaps in data that could guide future research. 


\section{Table of Contents}

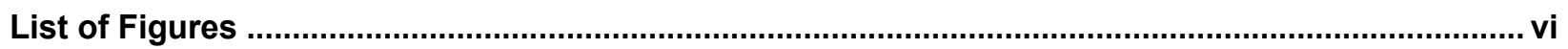

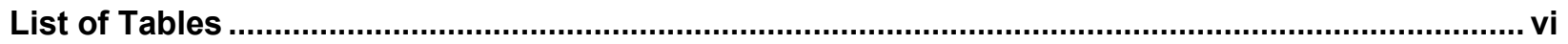

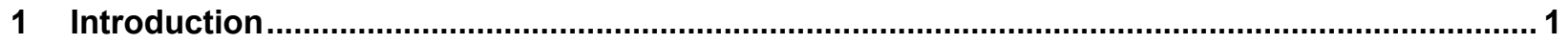

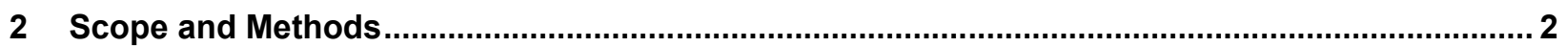

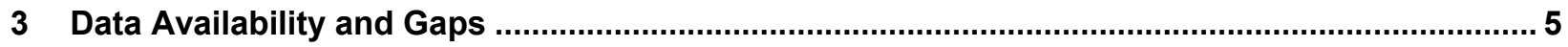

4 Results: Water Consumption and Withdrawal Factors ….................................................... 6

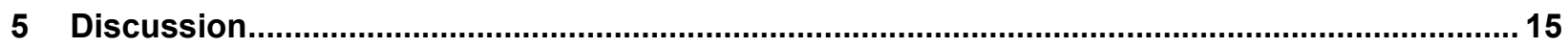

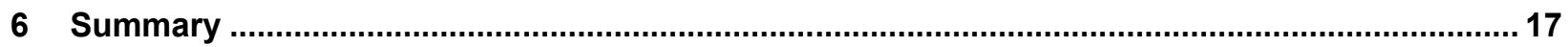

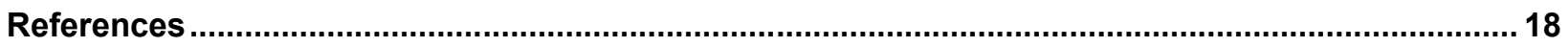




\section{List of Figures}

Figure 1. Operational water consumption factors for electricity generating technologies ............ 7

Figure 2. Operational water consumption factors for geothermal technologies .......................... 8

Figure 3. Operational water withdrawals for electricity generating technologies ..................... 9

Figure 4. Operational water withdrawal factors for recirculating cooling technologies ..............10

\section{List of Tables}

Table 1. Water Consumption Factors for Renewable Technologies (gal/MWh) 12

Table 2. Water Consumption Factors for Non-renewable Technologies (gal/MWh) ................ 13

Table 3. Water Withdrawal Factors for Electricity Generating Technologies (gal/MWh) 14 


\section{Introduction}

Thermoelectric power use has a significant impact on water resources and the power sector is highly dependent on these water resources; the United States Geological Survey (USGS) estimated on a national level that $41 \%$ of all freshwater withdrawals in the United States in 2005 were for thermoelectric power operations, primarily for cooling needs [1]. The power sector is thus highly vulnerable to changes in water resources, especially those that may result from potential climatic changes [2-5]. Increasingly, state agencies in California and New York have taken policy actions to address the impacts of power plants' water use and the environmental impacts of their cooling systems [6, 7]. Furthermore, the 2007 drought in the Southeast exposed many thermal generators, including Brown's Ferry nuclear plant, to water-related shut downs and curtailments due to unlawfully high discharge temperature and shallow or exposed cooling water inlet locations [8]. Effective integrated energy and water policy planning will require identifying the individual and cumulative impacts that power plant configurations have on water resources and the vulnerabilities of specific power plants to changes in water resources. Various studies have attempted to consolidate published estimates of water use impacts of electricity generating technologies, resulting in a wide range of technologies and values based on different primary sources of literature [9-14]. The goal of this work is to consolidate the various primary literature estimates of water use during the generation of electricity by conventional and renewable electricity generating technologies in the United States to more completely convey the variability and uncertainty associated with water use in electricity generating technologies. Individual water use factors, reported in terms of the volume of water used per unit of electrical output (gallons per megawatt-hour), are technology and cooling system specific. These water use factors can be incorporated into energy-economic models to estimate generation-related water use under different projected electricity portfolio scenarios. 


\section{Scope and Methods}

We evaluate two aspects of water usage: withdrawal and consumption. According to the USGS, "withdrawal" is defined as the amount of water removed from the ground or diverted from a water source for use, while "consumption" refers to the amount of water that is evaporated, transpired, incorporated into products or crops, or otherwise removed from the immediate water environment [1]. Both water withdrawal and consumption values are important indicators for water managers determining power plant impacts and vulnerabilities associated with water resources.

We consider water withdrawals and consumption for the operational phase only. Operational water use in this study includes cleaning, cooling, and other process-related needs that occur during electricity generation, such as flue gas desulfurization (FGD) in coal facilities. For the vast majority of power generation technologies, most of the water used in the life cycle of the plant occurs during the operational phase, with the exception of non-thermal renewable energy technologies that do not require cooling systems [9]. In addition, compared to the operational phase, data for the water requirements of other phases (such as the fuel cycle) are scarce, are subject to greater definitional boundary differences, and have more site-specific differences. Also, although the location of the plant is permanent, the locations of the manufacturing or fuel sources are not permanent. Given this and the continuous local impacts of power plant water use on water resources during the operational phase, we limit this study to a detailed review of only the operational water requirements of electricity generating technologies.

The energy technologies addressed here consist of configurations of concentrating solar power (CSP), solar photovoltaic (PV), wind, biopower, geothermal, hydroelectric, nuclear, natural gas, and coal technologies. Cooling system technologies considered include wet recirculating technologies (evaporative cooling towers), once-through cooling systems (open loop cooling), air-cooled condensing (dry cooling), hybrid wet and dry cooling systems (hybrid cooling), and pond cooling systems.

Electricity generating technologies use water for different processes, depending on their configuration. Thermal electricity technologies (e.g., CSP, biopower, coal, nuclear, and natural gas technologies) generally require water as the working fluid (and as the cooling medium to condense steam) as part of the Rankine cycle, the thermodynamic process that drives the steam engine [15]. CSP facilities use water for steam cycle processes, for cleaning mirrors or heliostats, and for cooling if a cooling tower is used. PV systems require occasional panel washing. Wind systems require very little water, if any, for cleaning. Biopower facilities use water for cooling and for steam cycle processing. Upstream water needs for growing energy crops are not included in this analysis but can be quite substantial (approximately 100 times greater than operational cooling system needs) and can vary greatly depending on region, crop, and production methods [16-18]. Geothermal technology configurations (e.g., dry steam, binary, and flash) can differ greatly in their use of water due to differences in reinjection techniques as well as vapor temperature and mass [19]. Enhanced Geothermal Systems (EGS) operate similar to geothermal binary technologies yet also require some additional water for hydraulic stimulation [19]. Water used in geothermal technologies may come from geothermal fluids, with little to no impact on local freshwater sources [20]. Over time, however, some geothermal plant efficiencies may decline and may require outside fresh or brackish water sources, and some technologies 
may lower local water tables [19,21]. Hydroelectric facilities using reservoirs have evaporative losses resulting from the dammed water $[22,23]$. Nuclear, natural gas, and coal facilities use water for cooling and for steam cycle processes. Coal facilities may also use water for FGD. Fossil technologies employing carbon capture and storage capabilities will require additional process water requirements [12].

Estimates of water consumption and withdrawal are displayed irrespective of geographic location, as many published data do not specify the location or climatic conditions of the plant. The location of a plant, and its corresponding climatic conditions, can affect its overall efficiency and thus its water use rate [24-27]. Similar fossil plants utilizing cooling towers may have water consumption and withdrawal factors that differ by more than $16 \%$, depending on the location in the United States [28]. Similarly, water consumption factors of CSP plants utilizing cooling towers may differ by as much as $20 \%$ [15]. Inter-annual variations in water intensity are also not considered for this review. Withdrawal and consumption factors are often reported in terms of annual averages, yet water intensity of facilities may change by as much as $16 \%$ as a result of diurnal and seasonal variations in temperatures, wind speeds, and humidity levels [28]. Other factors that may influence water use intensities of power plants that are not considered here include the age of the plant, the thermal efficiency of the plant, the age of the cooling system, and the water source $[26,27]$.

Certain aggregations of fuel technology types and cooling system types were made to facilitate analyses. Nuclear technologies include pressurized water reactors and boiling water reactors. Coal technologies make no distinction between wet, dry, and no FGD. For recirculating cooling technologies, no distinction is made between natural draft and mechanical draft cooling tower systems. All pond-cooled systems are treated identically. Pond-cooled systems can be operated in manners that resemble both recirculating systems and once-through systems as well as in hybrids of these technologies [29]. Different configurations and operating practices of pondcooled systems can lead to widely different reported water withdrawal and consumption values. No distinction is made between water types, which may include freshwater (surface and groundwater), saline water, or municipal waste water. In $2005,71 \%$ of thermoelectric water withdrawals were from freshwater sources [1]. Saline withdrawals are primarily concentrated in California, Florida, and the coastal Northeast, with the rest of the country relying on freshwater.

Data sources include published academic literature, state and federal government agency reports, non-governmental organizations' reports, and industry submissions to government agencies for permitting procedures. Estimates of national average water use intensity for particular technologies, estimates of existing plant operational water use, and estimates derived from laboratory experiments were considered equally. Certain sources report ranges of water consumption and withdrawal factors in place of specific values. If traceable individual case studies form the basis for the range given, the individual values are included as independent estimates within the set of estimates that are statistically analyzed. If a range is given and the underlying data points are not given, then the midpoint of that range is used for calculating an average value, and the high and low extremes are used for determining extreme ranges. This method of addressing ranges may lead to a bias toward data sources reporting explicit cases and may also underestimate actual water use at facilities, as it was observed that the midpoint of the range of extremes are in general less than values reported from individual facilities. This review did not alter (except for unit conversion) or audit for accuracy the estimates of water use 
published. Because estimates are used as published, considerable methodological inconsistency is inherent, limiting comparability. We report minimum, maximum, and median values for fuel technology and cooling system combinations in tables and additionally show $25^{\text {th }}$ and $75^{\text {th }}$ percentile data in figures. Due to the wide range of values reported from a small number of sources, median values may differ significantly from mean values. Upon request, raw data are available from the authors. 


\section{Data Availability and Gaps}

Although the power sector is the largest user of water in the nation, national statistics on the consumption and withdrawal rates of individual power plants are characterized by inconsistencies and scarcity [30]. Power sector water use data on a national level are collected by two federal agencies, the USGS and the U.S. Department of Energy's Energy Information Administration (EIA). The USGS reports water withdrawals for thermoelectric power production by county and sector every five years; water consumption values for thermoelectric power production were last reported for 1995 [31]. These data are collected by state agencies that do not always utilize the same methods or definitions in determining water withdrawals [1].

EIA provides official energy statistics on an annual basis, and EIA Form 923 reports, among other data, annual water withdrawal, discharge, and consumption rates in Schedule 8D, providing similar definitions of withdrawal and consumption as the USGS [29]. However, data are not entirely comprehensive and have omitted nuclear facilities and some natural gas combined cycle technologies [32]. Additionally, the quality of data is also of concern with power plants reporting data; many of the power plants report water withdrawal and consumption values that are far below or above detailed engineering studies of water use in power plants considered in this review. The National Energy Technology Laboratory compiled water use data in their 2007 Coal Power Plant DataBase [33]. However, this database is limited by the data availability and quality of EIA datasets. No similar public database has been developed for natural gas or nuclear generating facilities.

Detailed engineering studies and more general assessments of water use at individual thermoelectric power plants are uneven in their treatment of fuel technologies and cooling systems. For example, water consumption data for coal, natural gas, nuclear, and parabolic trough CSP facilities using a wet recirculating cooling system are relatively abundant. Fewer studies are available addressing water withdrawals for all technologies or water consumption for once-through, pond, and dry-cooling systems. Very little data exist for dedicated biomass, geothermal, and power tower CSP facilities.

Additionally, boundary conditions of water use studies are not always clear or consistent; some sources only report aggregated operational water usage, whereas other reports include water use by individual processes. However, the particular processes included in disaggregated studies may not be equivalent; the inclusion of FGD water requirements in coal facilities is one example where its explicit or implicit consideration is inconsistent across datasets. Geothermal facilities add an additional layer of complexity, as often cooling processes can make use of geothermal fluids rather than freshwater; some sources exclude geothermal fluids from calculations whereas others include geothermal fluids. Estimates of evaporation from hydropower reservoirs are complicated by the multiple uses of reservoirs (e.g., water supply, recreation, and flood control) and the different methods of allocating evaporation to electricity production $[22,23]$. Hydropower estimates are reported according to the allocation methods utilized in the published reports, which allocate all reservoir evaporation to power production. 


\section{Results: Water Consumption and Withdrawal Factors}

The cooling system employed is often a greater determinant of water usage than the particular technology generating electricity, both in terms of water consumption (Figures 1 and 2) and water withdrawal (Figures 3 and 4). Once-through cooling technologies withdraw 10 to 100 times more water per unit of electric generation than cooling tower technologies, yet cooling tower technologies consume at least twice as much water as once-through cooling technologies. Water consumption for dry cooling at CSP, biopower, and natural gas combined cycle plants is an order of magnitude less than for recirculating cooling at each of those types of plants. 


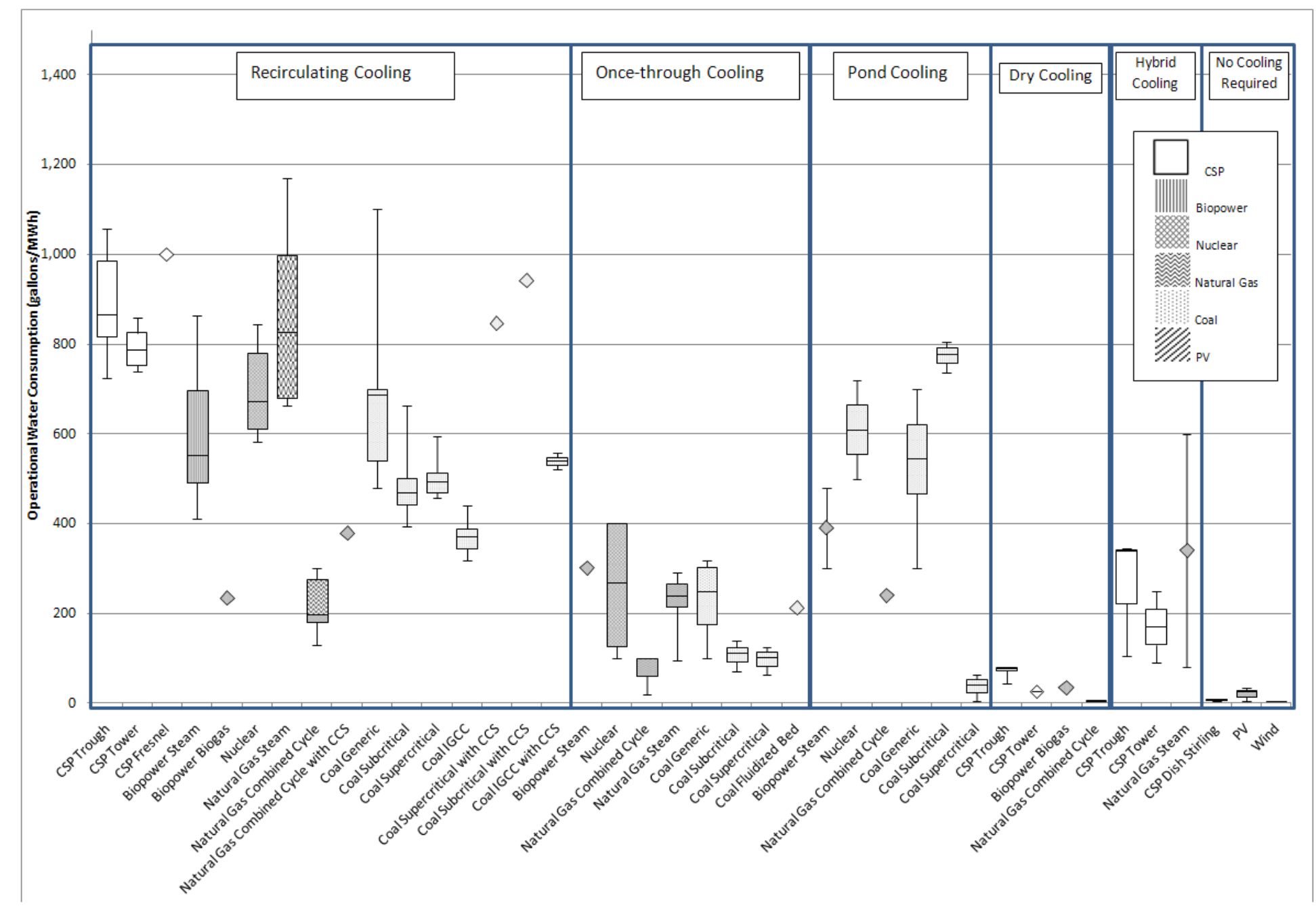

Figure 1. Operational water consumption factors for electricity generating technologies

IGCC: Integrated gasification combined cycle. CCS: Carbon capture and sequestration. CSP: Concentrating solar power. Whisker ends represent maxima and minima. Upper and lower ends of boxes represent $75^{\text {th }}$ and $25^{\text {th }}$ percentile, respectively. Horizontal lines in boxes represent medians. 


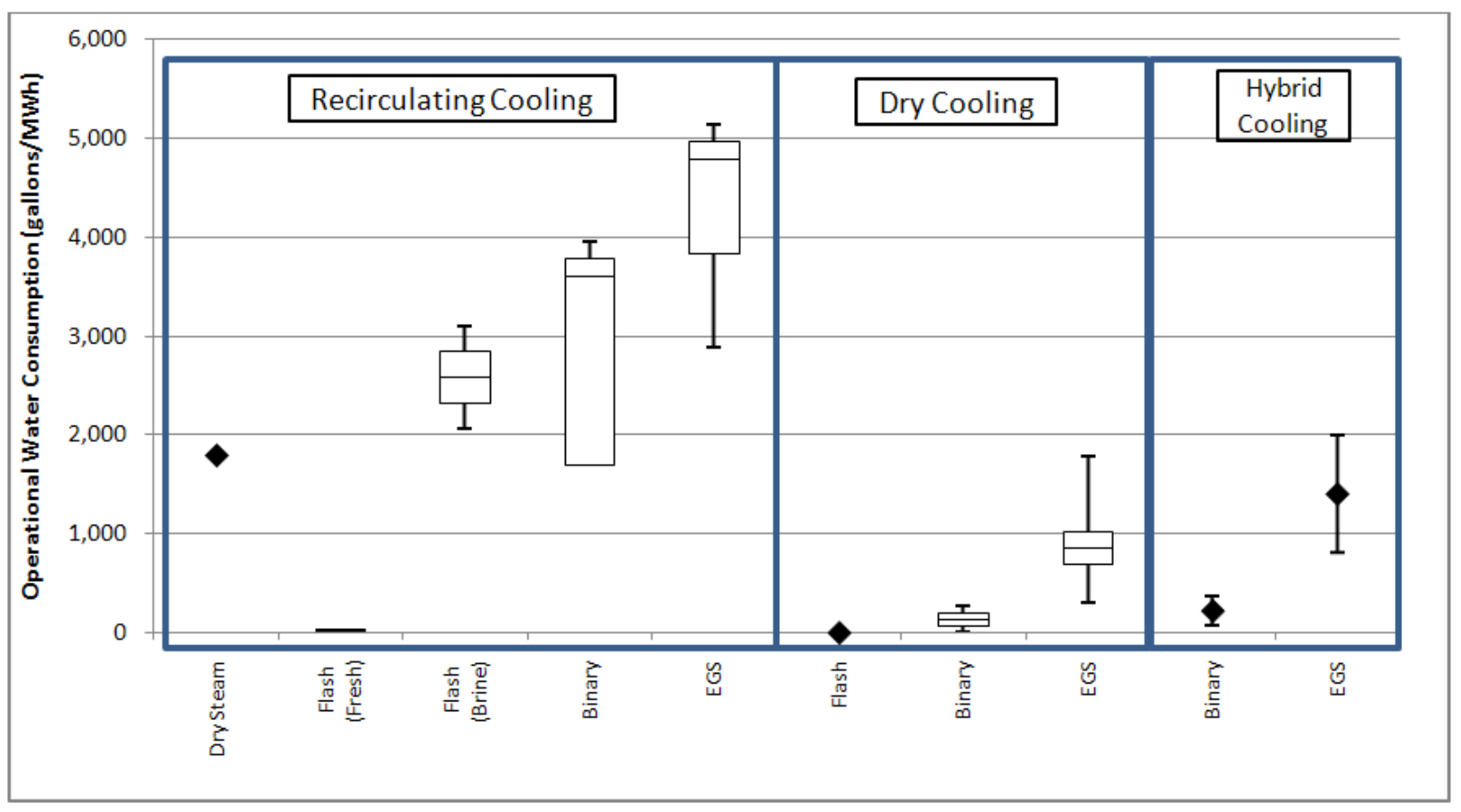

Figure 2. Operational water consumption factors for geothermal technologies

EGS: Enhanced geothermal systems. Whisker ends represent maxima and minima. Upper and lower ends of boxes represent $75^{\text {th }}$ and $25^{\text {th }}$ percentile, respectively. Horizontal lines in boxes represent medians. 


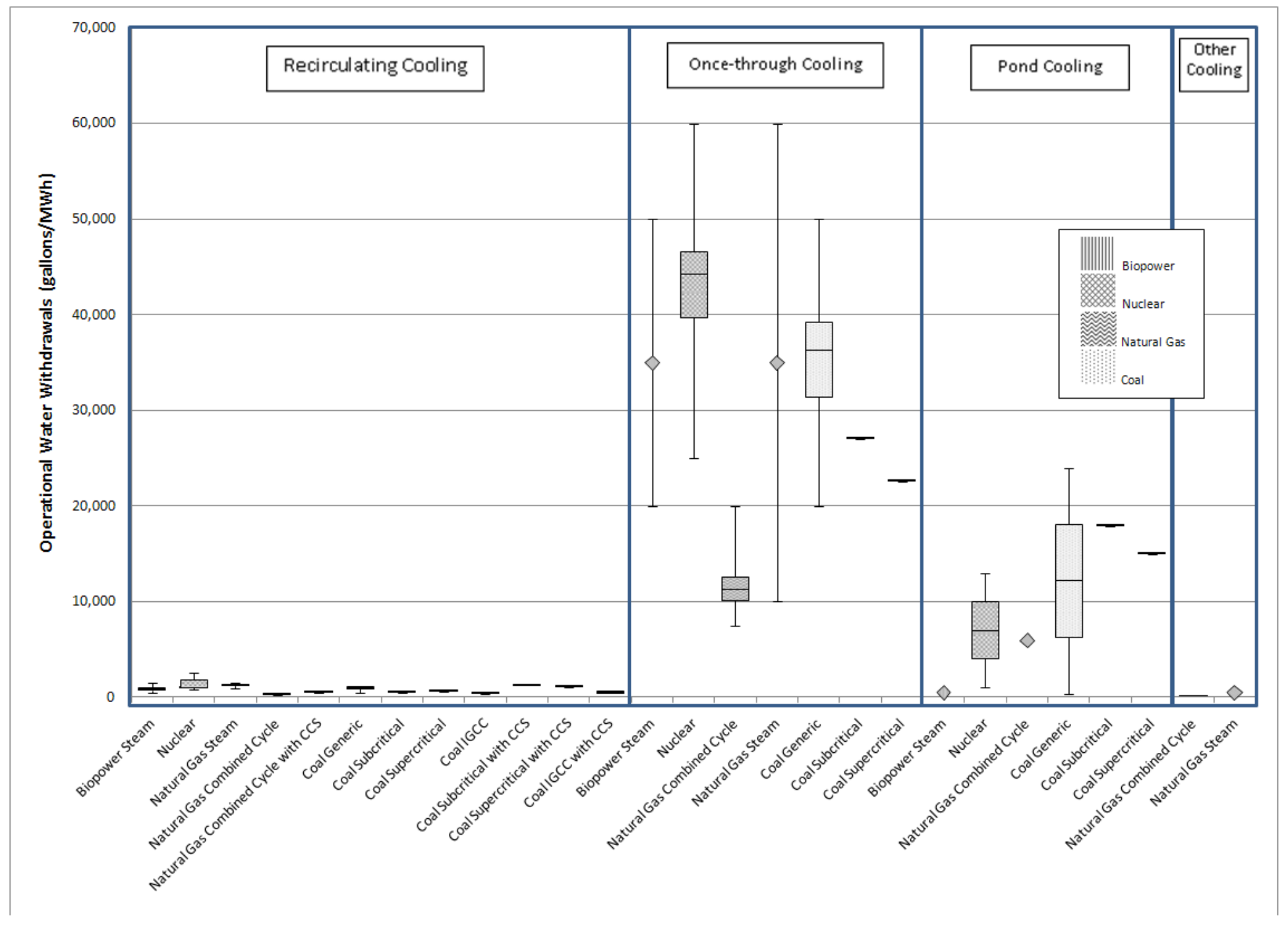

Figure 3. Operational water withdrawals for electricity generating technologies

IGCC: Integrated gasification combined cycle. CCS: carbon capture and storage. Whisker ends represent maxima and minima. Upper and lower ends of boxes represent $75^{\text {th }}$ and $25^{\text {th }}$ percentile, respectively. Horizontal lines in boxes represent medians. Recirculating cooling withdrawal values are also shown in Figure 4. 


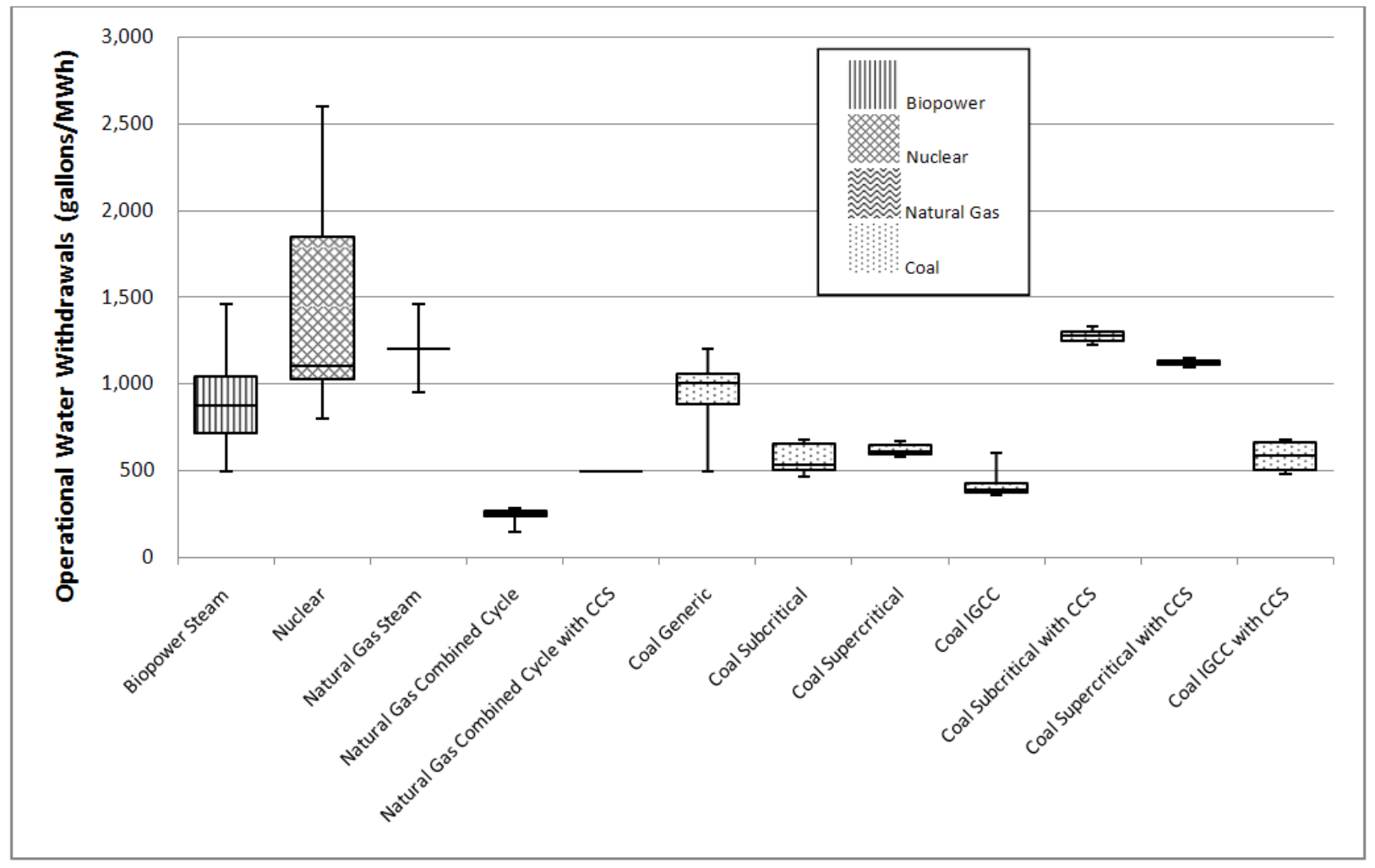

Figure 4. Operational water withdrawal factors for recirculating cooling technologies

IGCC: Integrated gasification combined cycle. CCS: carbon capture and storage. Whisker ends represent maxima and minima. Upper and lower ends of boxes represent $75^{\text {th }}$ and $25^{\text {th }}$ percentile, respectively. Horizontal lines in boxes represent medians. 
Water consumption factors for renewable (Table 1) and non-renewable (Table 2) electricity generating technologies vary substantially within and across technology categories. The highest water consumption factors for all technologies result from the use of evaporative cooling towers. With the exception of hydropower, pulverized coal with carbon capture and CSP technologies utilizing a cooling tower represent the upper bound of water consumption, at approximately $1,000 \mathrm{gal} / \mathrm{MWh}$ of electricity production. The lowest operational water consumption factors result from wind energy, PV, and CSP Stirling solar technologies and natural gas combined cycle facilities that employ dry cooling technologies. Water withdrawal factors for electricity generating technologies show a similar variability within and across technology categories (Table 3). The highest water withdrawal values result from nuclear technologies, whereas the smallest withdrawal values are for non-thermal renewable technologies. Consistent with literature, withdrawal factors for CSP, wind, geothermal, and PV systems are assumed to be equivalent to consumption factors. 
Table 1. Water Consumption Factors for Renewable Technologies (gal/MWh)

\begin{tabular}{|c|c|c|c|c|c|c|c|}
\hline Fuel Type & Cooling & Technology & Median & Min & Max & $n$ & Sources \\
\hline PV & $\mathrm{N} / \mathrm{A}$ & Utility Scale PV & 26 & 0 & 33 & 3 & {$[10,34,35]$} \\
\hline Wind & $\mathrm{N} / \mathrm{A}$ & Wind Turbine & 0 & 0 & 1 & 2 & {$[11,36]$} \\
\hline \multirow{8}{*}{ CSP } & \multirow{3}{*}{ Tower } & Trough & 865 & 725 & 1,057 & 17 & {$[10,34,37-46]$} \\
\hline & & Power Tower & 786 & 740 & 860 & 4 & [34, 39-41] \\
\hline & & Fresnel & 1,000 & 1,000 & 1,000 & 1 & [47] \\
\hline & \multirow{2}{*}{ Dry } & Trough & 78 & 43 & 79 & 10 & {$[38,42-44]$} \\
\hline & & Power Tower & 26 & 26 & 26 & 1 & {$[48]$} \\
\hline & \multirow{2}{*}{ Hybrid } & Trough & 338 & 105 & 345 & 3 & {$[42,47]$} \\
\hline & & Power Tower & 170 & 90 & 250 & 2 & [47] \\
\hline & $\mathrm{N} / \mathrm{A}$ & Stirling & 5 & 4 & 6 & 2 & {$[34,49]$} \\
\hline \multirow{5}{*}{ Biopower } & \multirow{2}{*}{ Tower } & Steam & 553 & 480 & 965 & 4 & [49-51] \\
\hline & & Biogas & 235 & 235 & 235 & 1 & {$[52]$} \\
\hline & Once-through & Steam & 300 & 300 & 300 & 1 & {$[50]$} \\
\hline & Pond & Steam & 390 & 300 & 480 & 1 & {$[50]$} \\
\hline & Dry & Biogas & 35 & 35 & 35 & 1 & {$[51]$} \\
\hline \multirow{10}{*}{ Geothermal $^{1}$} & \multirow{5}{*}{ Tower } & Dry Steam & 1,796 & 1,796 & 1,796 & 1 & {$[10]$} \\
\hline & & Flash (freshwater) & 10 & 5 & 19 & 3 & {$[19,20,49]$} \\
\hline & & Flash (geothermal fluid) & 2,583 & 2,067 & 3,100 & 2 & [53] \\
\hline & & Binary & 3,600 & 1,700 & 3,963 & 3 & {$[10,54,55]$} \\
\hline & & EGS & 4,784 & 2,885 & 5,147 & 4 & {$[10,51,54,55]$} \\
\hline & \multirow{3}{*}{ Dry } & Flash & 0 & 0 & 0 & 1 & {$[51]$} \\
\hline & & Binary & 135 & 0 & 270 & 2 & {$[19,51]$} \\
\hline & & EGS & 850 & 300 & 1,778 & 2 & {$[19,51]$} \\
\hline & \multirow{2}{*}{ Hybrid } & Binary & 221 & 74 & 368 & 1 & {$[56]$} \\
\hline & & EGS & 1,406 & 813 & 1,999 & 2 & {$[51,56]$} \\
\hline Hydropower & $\mathrm{N} / \mathrm{A}$ & $\begin{array}{c}\text { Aggregated in-stream and } \\
\text { reservoir }\end{array}$ & 4,491 & 1,425 & 18,000 & 3 & {$[22,23]$} \\
\hline
\end{tabular}

\footnotetext{
${ }^{1}$ Most geothermal facilities can use geothermal fluids or freshwater for cooling.
} 
Table 2. Water Consumption Factors for Non-renewable Technologies (gal/MWh)

\begin{tabular}{|c|c|c|c|c|c|c|c|}
\hline Fuel Type & Cooling & Technology & Median & Min & Max & $n$ & Sources \\
\hline \multirow{3}{*}{ Nuclear } & Tower & Generic & 672 & 581 & 845 & 6 & {$[10,14,27,50,57]$} \\
\hline & $\begin{array}{l}\text { Once- } \\
\text { through }\end{array}$ & Generic & 269 & 100 & 400 & 4 & {$[27,50,57,58]$} \\
\hline & Pond & Generic & 610 & 560 & 720 & 2 & {$[27,50]$} \\
\hline \multirow{8}{*}{$\begin{array}{l}\text { Natural } \\
\text { Gas }\end{array}$} & \multirow{3}{*}{ Tower } & Combined Cycle & 198 & 130 & 300 & 5 & {$[13,34,50,57,59]$} \\
\hline & & Steam & 826 & 662 & 1,170 & 4 & {$[10,14,49,60]$} \\
\hline & & Combined Cycle with CCS & 378 & 378 & 378 & 1 & {$[59]$} \\
\hline & \multirow{2}{*}{$\begin{array}{l}\text { Once- } \\
\text { through }\end{array}$} & Combined Cycle & 100 & 20 & 100 & 3 & {$[50,57,60]$} \\
\hline & & Steam & 240 & 95 & 291 & 2 & {$[10,49]$} \\
\hline & Pond & Combined Cycle & 240 & 240 & 240 & 1 & {$[57]$} \\
\hline & Dry & Combined Cycle & 2 & 0 & 4 & 2 & {$[50,57]$} \\
\hline & Inlet & Steam & 340 & 80 & 600 & 1 & [49] \\
\hline \multirow{13}{*}{ Coal } & \multirow{7}{*}{ Tower } & Generic & 687 & 480 & 1,100 & 5 & {$[10,14,27,50,58]$} \\
\hline & & Subcritical & 471 & 394 & 664 & 6 & {$[13,57,59,61]$} \\
\hline & & Supercritical & 493 & 458 & 594 & 6 & {$[13,57,59,61]$} \\
\hline & & IGCC & 372 & 318 & 439 & 7 & {$[13,59]$} \\
\hline & & Subcritical with CCS & 942 & 942 & 942 & 1 & [59] \\
\hline & & Supercritical with CCS & 846 & 846 & 846 & 1 & [59] \\
\hline & & IGCC with CCS & 540 & 522 & 558 & 3 & [59] \\
\hline & \multirow{3}{*}{$\begin{array}{l}\text { Once- } \\
\text { through }\end{array}$} & Generic & 250 & 100 & 317 & 4 & {$[10,27,50,58]$} \\
\hline & & Subcritical & 113 & 71 & 138 & 3 & {$[57]$} \\
\hline & & Supercritical & 103 & 64 & 124 & 3 & {$[57]$} \\
\hline & \multirow{3}{*}{ Pond } & Generic & 545 & 300 & 700 & 2 & {$[27,50]$} \\
\hline & & Subcritical & 779 & 737 & 804 & 3 & [57] \\
\hline & & Supercritical & 42 & 4 & 64 & 3 & [57] \\
\hline
\end{tabular}


Table 3. Water Withdrawal Factors for Electricity Generating Technologies (gal/MWh)

\begin{tabular}{|c|c|c|c|c|c|c|c|}
\hline Fuel Type & Cooling & Technology & Median & Min & Max & $n$ & Sources \\
\hline \multirow{3}{*}{ Nuclear } & Tower & Generic & 1,101 & 800 & 2,600 & 3 & {$[27,50,57]$} \\
\hline & Once-through & Generic & 44,350 & 25,000 & 60,000 & 4 & {$[27,50,57,58]$} \\
\hline & Pond & Generic & 7,050 & 500 & 13,000 & 2 & {$[27,50]$} \\
\hline \multirow{8}{*}{$\begin{array}{l}\text { Natural } \\
\text { Gas }\end{array}$} & \multirow{3}{*}{ Tower } & Combined Cycle & 253 & 150 & 283 & 6 & {$[12,13,50,57,59]$} \\
\hline & & Steam & 1,203 & 950 & 1,460 & 2 & {$[49,60]$} \\
\hline & & $\begin{array}{c}\text { Combined Cycle with } \\
\text { CCS }\end{array}$ & 496 & 487 & 506 & 2 & {$[12,59]$} \\
\hline & \multirow{2}{*}{ Once-through } & Combined Cycle & 11,380 & 7,500 & 20,000 & 2 & {$[50,57]$} \\
\hline & & Steam & 35,000 & 10,000 & 60,000 & 1 & [49] \\
\hline & Pond & Combined Cycle & 5,950 & 5,950 & 5,950 & 1 & {$[57]$} \\
\hline & Dry & Combined Cycle & 2 & 0 & 4 & 2 & {$[50,57]$} \\
\hline & Inlet & Steam & 425 & 100 & 750 & 1 & [49] \\
\hline \multirow{13}{*}{ Coal } & \multirow{7}{*}{ Tower } & Generic & 1,005 & 500 & 1,200 & 4 & {$[27,35,50,58]$} \\
\hline & & Subcritical & 531 & 463 & 678 & 7 & {$[12,13,57,59,61]$} \\
\hline & & Supercritical & 609 & 582 & 669 & 7 & {$[12,13,57,59,61]$} \\
\hline & & IGCC & 390 & 358 & 605 & 11 & {$[12,13,35,59]$} \\
\hline & & Subcritical with CCS & 1,277 & 1,224 & 1,329 & 2 & {$[12,59]$} \\
\hline & & Supercritical with CCS & 1,123 & 1,098 & 1,148 & 2 & {$[12,59]$} \\
\hline & & IGCC with CCS & 586 & 479 & 678 & 6 & {$[12,59]$} \\
\hline & \multirow{3}{*}{ Once-through } & Generic & 36,350 & 20,000 & 50,000 & 4 & {$[11,27,50,58]$} \\
\hline & & Subcritical & 27,088 & 27,046 & 27,113 & 3 & {$[57]$} \\
\hline & & Supercritical & 22,590 & 22,551 & 22,611 & 3 & {$[57]$} \\
\hline & \multirow{3}{*}{ Pond } & Generic & 12,225 & 300 & 24,000 & 2 & {$[27,50]$} \\
\hline & & Subcritical & 17,914 & 17,859 & 17,927 & 3 & {$[57]$} \\
\hline & & Supercritical & 15,046 & 14,996 & 15,057 & 3 & [57] \\
\hline \multirow{3}{*}{ Biopower } & Tower & Steam & 878 & 500 & 1,460 & 2 & [49] \\
\hline & Once-through & Steam & 35,000 & 20,000 & 50,000 & 1 & [50] \\
\hline & Pond & Steam & 450 & 300 & 600 & 1 & [50] \\
\hline
\end{tabular}




\section{Discussion}

Despite methodological differences in data, general trends can be observed and broad conclusions can be drawn from the breadth of data collected. A transition to a less carbonintensive electricity sector could result in either an increase or decrease in water consumption per unit of electricity generated, depending on the choice of technologies and cooling systems employed. Non-thermal renewable technologies, such as wind and PV systems, consume minimal amounts of water per unit of generation. However, the highest water consumption factors considered in this study, excluding geothermal and hydroelectric facilities, which can have high water intensities but also have important caveats, are low-carbon emitting technologies that utilize cooling towers: pulverized coal with carbon capture technologies and CSP systems. Decisions affecting the power sector's impact on the climate may need to include water considerations to avoid negative unintended environmental consequences on water resources. This can be addressed by integrated energy and water policy planning, as the availability of water in certain jurisdictions may limit the penetration of these technologies and cooling system configurations.

Freshwater use impacts can be reduced by utilizing dry cooling or by using non-freshwater sources as a cooling medium. Initial work suggests that the performance penalty for CSP facilities switching from wet cooling to dry cooling results in an annual reduction in output of $2 \%-5 \%$ and an increase in the levelized cost of producing energy of $3 \%-8 \%$, depending on local climatic conditions [15]. Using national averages, the annual performance penalty for switching from wet cooling to dry cooling for nuclear plants is $6.8 \%$, combined cycle plants $1.7 \%$, and other fossil plants (including coal and natural gas steam plants) 6.9\% [62]. Further efforts are needed to evaluate performance and cost penalties associated with utilizing dry or hybrid cooling systems for fossil fuel facilities using carbon capture technologies. Utilizing reclaimed water, such as municipal wastewater, is another approach that could lessen the impact of the power sector on freshwater resources and wastewater treatment facilities. The legal and physical availability of municipal wastewater, especially in rural areas, may be a limiting factor to its widespread usage, and the cost and performance penalties of utilizing such sources must be investigated further [63].

The choice of cooling system may play an important role in the development of our future electricity mix. Differences between cooling systems can have substantial environmental impacts on local water resources [64-66]. Employing wet cooling technologies (i.e., once-through and cooling tower technologies) imposes an inherent tradeoff between relatively high water consumption and relatively high water withdrawals, which has important implications for regional cooling system policies and regulations. A reduction in withdrawals (but a corresponding increase in consumption) may benefit a watershed that has an abundance of water but may lead to concerns in an area that is already lacking water. A shift away from, for example, once-through cooling systems in coastal areas that withdraw saline water, to inland recirculating systems such as cooling towers that primarily consume freshwater, will impact watersheds and water availability differently depending on local conditions. The use of alternative cooling technologies may serve as an energy security benefit for utilities and communities, given uncertainties in future scenarios of water availability and expected vulnerabilities for power plants [4, 5]. Reduced levels in bodies of water, or substantial increases in the temperature of these bodies of water, may require thermal power plants to run at lower 
capacities or to shut down completely, as was seen in France in 2003 [67]. Utilizing dry cooling or non-freshwater sources avoids some of the risks associated with these drought and climate change scenarios.

Accurate estimates of water use in individual power plants, and the effect of this water use on a regional scale, will be elusive until more studies are conducted for the variety of technologies and cooling systems currently in operation along with those expected to be developed and deployed. Furthermore, calibration of these values on national and regional scales will remain challenging until methods for collecting and evaluating data by federal agencies has improved. Nonetheless, certain conclusions regarding the overall impact power plants have on water resources can be drawn on regional levels from existing water use data.

Further studies with consistent boundary conditions and methods are necessary to develop water consumption and withdrawal estimates for certain technologies and cooling systems to fully understand reasons for variations in data that are not attributable to climatic factors or technology vintages. To better understand how cooling system and technology system decisions will be made in the future, analyses using energy-economic models will require improved data on water availability and regional water use factors. Existing data collected from federal agencies are currently inconsistent and incomplete [30]. However, in 2009, the U.S. Government Accountability Office released a report calling for improvements in federal agency water data collection in power plants; EIA is currently working with the USGS and other federal agencies to improve the scope and quality of its data collection [30]. Such efforts should improve the availability of power plant specific data and the ability to calibrate model estimates. 


\section{Summary}

We reviewed primary literature for data on water withdrawal and consumption factors for electricity generation in the United States and have consolidated them in this study. These detailed water consumption and withdrawal factors can be utilized in energy-economic and transmission planning models to better understand the regional and national impacts on water resources for various electricity future scenarios and can inform policy analysis at a national and local level. Improved power plant data gathered on a regional level and further studies into the water requirements of existing and emerging technologies (such as carbon capture technologies) are necessary to assess the water impacts of a developing decarbonizing economy in more detail. 


\section{References}

1. Kenny, J.F.; Barber, N.L.; Hutson, S.S.; Linsey, K.S.; Lovelace, J.K.; Maupin, M.A. Estimated Use of Water in the United States in 2005. U.S. Geological Survey Circular 1344. Reston, VA: USGS, 2009; p. 52.

2. Vörösmarty, C.; Green, P.; Salisbury, J.; Lammers, R. "Global Water Resources: Vulnerability from Climate Change and Population Growth." Sci.; Vol. 289 (5477), 2000.

3. $\quad$ Bates, B.C.; Kundzewicz, Z.W.; Wu, S.; Palutikof, J.P. Climate Change and Water. Technical Paper of the Intergovernmental Panel on Climate Change. Geneva, Switzerland: IPCC, 2008.

4. $\quad$ Dai, A. "Drought Under Global Warming: A Review." Wiley Interdiscip. Rev.: Clim. Change; Vol. 2, 2010; pp. 45-65.

5. National Energy Technology Laboratory (NETL). Water Vulnerabilities for Existing Coal-fired Power Plants. DOE/NETL-2010/1429. Pittsburgh, PA: National Energy Technology Laboratory, 2010.

6. California State Lands Commission. Resolution by the California State Lands Commission Regarding Once-through Cooling in California Power Plants. Proposed April 13, 2006.

7. New York State Department of Environmental Conservation. Best Technology Available (BTA) for Cooling Water Intake Structures. Proposed March 4, 2010.

8. NETL. Impact of Drought on U.S. Steam Electric Power Plant Cooling Water Intakes and Related Water Resource Management Issues. DOE/NETL-2009/1364. Pittsburgh, PA: National Energy Technology Laboratory, 2009.

9. $\quad$ Fthenakis, V.; Kim, H.C. "Life-cycle Uses of Water in U.S. Electricity Generation." Renew. Sustain. Energy Rev.; Vol. 14, 2010; pp. 2039-2048.

10. Gleick, P. Water in Crisis: A Guide to the World's Fresh Water Resources. New York: Oxford University Press, 1993.

11. Inhaber, H. "Water Use in Renewable and Conventional Electricity Production." Energy Sources, Part A; Vol. 26, 2004; pp. 309-322.

12. NETL. Cost and Performance Baseline for Fossil Energy Plants-Volume 1: Bituminous Coal and Natural Gas to Electricity Final Report. DOE/NETL-2007/1281. Pittsburgh, PA: National Energy Technology Laboratory, 2007.

13. NETL. Power Plant Water Usage and Loss Study. 2007 Update. Pittsburgh, PA: National Energy Technology Laboratory, 2007.

14. Western Resource Advocates (WRA). A Sustainable Path: Meeting Nevada's Water and Energy Demands. Boulder, CO: Western Resource Advocates, 2008.

15. Turchi, C.; Wagner, M.; Kutscher, C. Water Use in Parabolic Trough Power Plants: Summary Results from WorleyParsons' Analyses. NREL/TP-5500-49468. Golden, CO: National Renewable Energy Laboratory, 2010.

16. Stone, K.C.; Hunt, P.G.; Cantrell, K.B.; Ro, K.S. "The Potential Impacts of Biomass Feedstock Production on Water Resource Availability." Bioresour.Technol.; Vol. 101, 2010; pp. 2014-2025.

17. Berndes, G. "Bioenergy and Water-The Implications of Large-scale Bioenergy Production for Water Use and Supply." Global Environ. Change; Vol. 12, 2002; pp. $253-271$. 
18. Berndes, G. "Future Biomass Energy Supply: The Consumptive Water Use Perspective." Int. J. Water Resour. Dev; Vol. 24, 2008; pp. 235-245.

19. Clark, C.; Harto, C.; Sullivan, J.; Wang, M. Water Use in the Development and Operation of Geothermal Power Plants. ANL/EVS/R-10/5. Argonne, IL: Argonne National Laboratory, 2011.

20. Kagel, A.; Bates, D.; Gawell, K. A Guide to Geothermal Energy and the Environment. Washington, DC: Geothermal Energy Association, 2007.

21. Bradbury, D. "Californian Groups Clash Over Geothermal Water Use." Bus. Green; 2009.

22. Gleick, P. "Environmental Consequences of Hydroelectric Development: The Role of Facility Size and Type." Energy; Vol. 17 (8), 1992; pp. 735-747.

23. Torcellini, P.; Long, N.; Judkoff, R. Consumptive Water Use for U.S. Power Production. NREL/TP-550-33905. Golden, CO: National Renewable Energy Laboratory, 2003.

24. Miller, B.A.; Alavian, V.; Bender, M.D.; Benton, D.J.; Ostrowski Jr., P.; Parsly, J.A.; Shiao, M.C. "Integrated Assessment of Temperature Change Impacts on the TVA Reservoir and Power Supply Systems." Hydraulic Engineering: Saving a Threatened Resource-In Search of Solutions: Proceedings of the Hydraulic Engineering Sessions at Water Forum '92; 1992; pp. 563-568.

25. Giusti, E.; Meyer, E. Water Consumption by Nuclear Power Plants and Some Hydrological Implications. U.S. Geological Survey Circular 745. Reston, VA: USGS, 1977.

26. Yang, X.; Dziegielewski, B. "Water Use by Thermoelectric Power Plants in the United States." J. Am. Water Resour. Assoc.; Vol. 43, 2007; pp. 160-169.

27. Dziegielewski, B.; Bik, T. Water Use Benchmarks for Thermoelectric Power Generation. Research Report of the Department of Geography and Environmental Resources. Carbondale, IL: Southern Illinois University, 2006.

28. Huston, R. An Overview of Water Requirements for Electric Power Generation. Water Management by the Electric Power Industry. Gloyna, E.; Woodson, H.; Drew, H., eds. Austin, TX: University of Texas Center for Research in Water Resources, 1975.

29. Energy Information Administration (EIA). Form EIA-923 Power Plant Operations Report Instructions, OMB No. 1905-0129, U.S. Department of Energy, 2011.

30. U.S. Government Accountability Office (GAO). Improvements to Federal Water Use Data would Increase Understanding of Trends in Power Plant Water Use. GAO 10-23. Washington, DC: U.S. Government Accountability Office, 2009.

31. Solley, W.; Pierce, R.; Perlman, H. Estimated Use of Water in the United States in 1995. U.S. Geological Survey Circular 1200. Reston, VA: USGS, 1999.

32. EIA. Form 906/920/923: Utility, Non-utility, and Combined Heat And Power Plant Database. 2007 Monthly Time Series. Washington, DC: U.S. Energy Information Administration, 2010.

33. NETL. 2007 Coal Plant Database. Pittsburgh, PA: National Energy Technology Laboratory, 2007.

34. Leitner, A. Fuel from the Sky: Solar Power's Potential for Western Energy Supply. NREL/SR 550-32160. Golden, CO: National Renewable Energy Laboratory, 2002.

35. Meridian. Energy System Emissions and Materiel Requirements. Report to U.S. Department of Energy, Alexandria, VA: Meridian Corporation, 1989. 
36. American Wind Energy Association. AWEA Estimate Based on Data Obtained in Personal Communication with Brian Roach, Fluidyne Corp., 1996.

http://archive.awea.org/faq/wwt environment.html\#How $\% 20$ much $\% 20$ water $\% 20$ do $\% 20$ wind $\% 20$ turbines $\% 20$ use $\% 20$ compared $\% 20$ with $\% 20$ conventional $\% 20$ power $\% 20$ plants. Accessed November 17, 2010.

37. Cohen, G.; Kearney, D.; Drive, C.; Mar, D.; Kolb, G. Final Report on the Operation and Maintenance Improvement Program for Concentrating Solar Plants. SAND99-1290. Albuquerque, NM: Sandia National Laboratories, 1999.

38. Kelly, B. Nexant Parabolic Trough Solar Power Plant Systems Analysis-Task 2: Comparison of Wet and Dry Rankine Cycle Heat Rejection. NREL/SR-550-40163. Golden, CO: National Renewable Energy Laboratory, 2006.

39. Sargent \& Lundy. Assessment of Parabolic Trough and Power Tower Solar Technology Cost and Performance Forecasts. NREL/SR-550-34440. Golden, CO: National Renewable Energy Laboratory, 2003.

40. Stoddard, L.; Abiecunas, J.; Connell, R.O. Economic, Energy, and Environmental Benefits of Concentrating Solar Power in California. NREL/SR-550-39291. Golden, CO: National Renewable Energy Laboratory, 2006.

41. Viebahn, P.; Kronshage, S.; Trieb, F.; Lechon, Y. Final Report on Technical Data, Costs, and Life Cycle Inventories of Solar Thermal Power Plants. 502687. Rome, Italy: New Energy Externalities Developments for Sustainability Project, 2008; pp. 1-95.

42. WorleyParsons. Beacon Solar Energy Project Dry Cooling Evaluation. Report No. FPLS-0-LI-450-0001. North Sydney, Australia: WorleyParsons, 2009.

43. WorleyParsons. Analysis of Wet and Dry Condensing 125 MW Parabolic Trough Power Plants. Report No. NREL-2-ME-REP-0002-R0. North Sydney, Australia:

WorleyParsons, 2009.

44. WorleyParsons. Material Input for Life Cycle Assessment Task 5 Subtask 2: O\&M Schedules. Report No. NREL-0-LS-019-0005. North Sydney, Australia: WorleyParsons, 2010.

45. WorleyParsons. Parabolic Trough Reference Plant for Cost Modeling with the Solar Advisor Model. North Sydney, Australia: WorleyParsons, 2010.

46. Kutscher, C.; Buys, A. Analysis of Wet/Dry Hybrid Cooling for a Parabolic Trough Power Plant. Golden, CO: National Renewable Energy Laboratory, 2006.

47. DOE. Concentrating Solar Power Commercial Application Study: Reducing Water Consumption of Concentrating Solar Power Electricity Generation. Report to Congress. Washington, DC: U.S. Department of Energy, 2009.

48. Brightsource_Energy. Application for Certification, Volumes I and II, for the Ivanpah Solar Electric Generating System. Submitted to California Energy Commission Docket Unit. Application For Certification (07-AFC-5), August 31, 2007.

49. California Energy Commission (CEC). 2007 Environmental Performance Report of California's Electrical Generation System. California Energy Commission Final Staff Report. Sacramento, CA: California Energy Commission, 2008.

50. Electric Power Research Institute (EPRI). Water and Sustainability (Volume 2): An Assessment of Water Demand, Supply, and Quality in the U.S.-The Next Half Century. Technical Report 1006785. Palo Alto, CA: Electric Power Research Institute, 2002.

51. EPRI; DOE. Renewable Energy Technology Characterizations. EPRI Topical Report109496. Palo Alto, CA: EPRI, 1997. 
52. Mann, M.; Spath, P. Life Cycle Assessment of a Biomass Gasification Combined-Cycle System. TP-430-23076. Golden, CO: National Renewable Energy Laboratory, 1997.

53. Layton, D. "Water-related Impacts of Geothermal Energy Production in California's Imperial Valley." 1979 Annual Meeting of the Geothermal Resources Council. CONF190906--18. Livermore, CA: Lawrence Livermore Laboratory, 1979.

54. Kozubal, E.; Kutscher, C. "Analysis of a Water-cooled Condenser in Series with an Aircooled Condenser for a Proposed 1-MW Geothermal Power Plant." Trans. - Geotherm. Resour. Counc.; Vol. 27, 2003.

55. EERE. Geothermal Technologies Program: Geothermal FAQs. Washington, DC: U.S. Department of Energy Office of Energy Efficiency and Renewable Energy, 2006.

56. Kutscher, C.; Costenaro, D. Assessment of Evaporative Cooling Enhancement Methods for Air-Cooled Geothermal Power Plants. NREL/CP-550-32394. Golden, CO: National Renewable Energy Laboratory, 2002.

57. NETL. Estimating Freshwater Needs to Meet Future Thermoelectric Generation Requirements. DOE/NETL-400/2009/1339. Pittsburgh, PA: National Energy Technology Laboratory, 2009.

58. Hoffmann, J.; Forbes, S.; Feeley, T. Estimating Freshwater Needs to Meet 2025 Electricity Generating Capacity Forecasts. Pittsburgh, PA: National Energy Technology Laboratory, 2004; pp. 1-12.

59. NETL. Cost and Performance Baseline for Fossil Energy Plants-Volume 1: Bituminous Coal and Natural Gas to Electricity-Revision 2. DOE/NETL-2010/1397. Pittsburgh, PA: National Energy Technology Laboratory, 2010.

60. Feeley, T.J.; Green, L.; Murphy, J.T.; Hoffmann, J.; Carney, B.A. Department of Energy/Office of Fossil Energy's Power Plant Water Management R\&D Program. Pittsburgh, PA: National Energy Technology Laboratory, 2005; pp. 1-18.

61. NETL. Existing Plants, Emissions and Capture - Setting Water-Energy R\&D Program Goals. DOE/NETL-2009/1372. Pittsburgh, PA: National Energy Technology Laboratory, 2009.

62. Environmental Protection Agency (EPA). Clean Water Act, in Section 316b. Chapter 3, U.S. Environmental Protection Agency. 2009.

63. EPRI. Use of Degraded Water Sources as Cooling Water in Power Plants. Technical Report 1005359. Palo Alto, CA: Electric Power Research Institute, 2003.

64. Carter, H.; Schubel, J.; Wilson, R. "Thermally Induced Biological Effects Caused by Once-through Cooling Systems: A Rationale for Evaluation." Environ. Manage.; Vol. 3, 1979; pp. 353-368.

65. Laws, E. Aquatic Pollution. 3rd edition. Hoboken, NJ: John Wiley and Sons, Inc, 2000.

66. Reynolds, J.Z. "Power Plant Cooling Systems: Policy Alternatives." Sci.; Vol. 207, 1980; pp. 367-372.

67. Poumadère, M. "The 2003 Heat Wave in France: Dangerous Climate Change Here and Now." Risk Anal.: An Off. Publi. Soc. Risk Anal.; Vol. 25, 2005; pp. 1483-1494. 


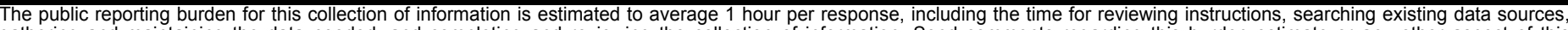

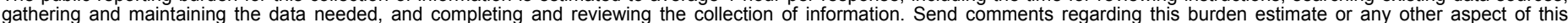

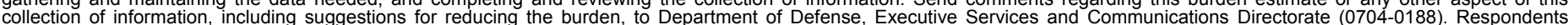

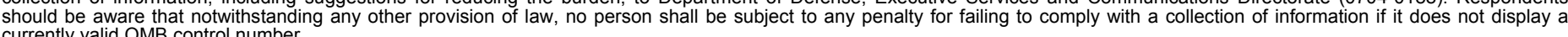

PLEASE DO NOT RETURN YOUR FORM TO THE ABOVE ORGANIZATION.

\begin{tabular}{l|l|l|l} 
1. REPORT DATE (DD-MM-YYYY) & 2. REPORT TYPE & 3. DATES COVERED (FrOm - TO)
\end{tabular} March 2011

Technical Report

4. TITLE AND SUBTITLE

A Review of Operational Water Consumption and Withdrawal

Factors for Electricity Generating Technologies 5a. CONTRACT NUMBER

DE-AC36-08G028308

5b. GRANT NUMBER

5c. PROGRAM ELEMENT NUMBER

5d. PROJECT NUMBER

NREL/TP-6A20-50900

5e. TASK NUMBER

DOCC. 1005

5f. WORK UNIT NUMBER
7. PERFORMING ORGANIZATION NAME(S) AND ADDRESS(ES)

National Renewable Energy Laboratory

1617 Cole Blvd.

Golden, CO 80401-3393

9. SPONSORING/MONITORING AGENCY NAME(S) AND ADDRESS(ES)

\section{PERFORMING ORGANIZATION REPORT NUMBER \\ NREL/TP-6A20-50900}

10. SPONSOR/MONITOR'S ACRONYM(S) NREL

11. SPONSORING/MONITORING AGENCY REPORT NUMBER

12. DISTRIBUTION AVAILABILITY STATEMENT

National Technical Information Service

U.S. Department of Commerce

5285 Port Royal Road

Springfield, VA 22161

13. SUPPLEMENTARY NOTES

14. ABSTRACT (Maximum 200 Words)

Various studies have attempted to consolidate published estimates of water use impacts of electricity generating technologies, resulting in a wide range of technologies and values based on different primary sources of literature. The goal of this work is to consolidate the various primary literature estimates of water use during the generation of electricity by conventional and renewable electricity generating technologies in the United States to more completely convey the variability and uncertainty associated with water use in electricity generating technologies.

\section{SUBJECT TERMS}

water consumption; water withdrawal; electricity generating technologies; geothermal; thermoelectric power; cooling systems; energy-economic model

\begin{tabular}{|c|c|c|c|c|}
\hline \multicolumn{3}{|c|}{ 16. SECURITY CLASSIFICATION OF: } & \multirow{2}{*}{$\begin{array}{l}\text { 17. LIMITATION } \\
\text { OF ABSTRACT } \\
\text { UL }\end{array}$} & \multirow{2}{*}{$\begin{array}{l}\text { 18. NUMBER } \\
\text { OF PAGES }\end{array}$} \\
\hline $\begin{array}{l}\text { a. REPORT } \\
\text { Unclassified }\end{array}$ & $\begin{array}{l}\text { b. ABSTRACT } \\
\text { Unclassified }\end{array}$ & $\begin{array}{l}\text { c. THIS PAGE } \\
\text { Unclassified }\end{array}$ & & \\
\hline
\end{tabular}

19a. NAME OF RESPONSIBLE PERSON

19b. TELEPHONE NUMBER (Include area code) 